\title{
Towards a Capture and Reuse Model for Aquaculture Effluent as a Hydroponic Nutrient Solution Using Aerobic Microbial Reactors
}

\author{
Joseph Tetreault ${ }^{1,2, *}$, Rachel Fogle $^{3}$ and Todd Guerdat ${ }^{1,4}$ \\ 1 Department of Agriculture, Nutrition, and Food Systems, University of New Hampshire, \\ Durham, NH 03824, USA; todd.guerdat@usda.gov \\ 2 Environmental Science Program, Harrisburg University of Science and Technology, \\ Harrisburg, PA 17101, USA \\ 3 Integrative Sciences Program, Harrisburg University of Science and Technology, Harrisburg, PA 17101, USA; \\ rfogle@harrisburgu.edu \\ 4 Natural Resources Conservation Services, United States Department of Agriculture, Epping, NH 03042, USA \\ * Correspondence: jtetreault@harrisburgu.edu
}

Citation: Tetreault, J.; Fogle, R.; Guerdat, T. Towards a Capture and Reuse Model for Aquaculture Effluent as a Hydroponic Nutrient Solution Using Aerobic Microbial Reactors. Horticulturae 2021, 7, 334. https://doi.org/10.3390/

Thorticulturae7100334

Academic Editor: Hye-Ji Kim

Received: 19 August 2021

Accepted: 21 September 2021

Published: 23 September 2021

Publisher's Note: MDPI stays neutral with regard to jurisdictional claims in published maps and institutional affiliations.

Copyright: (c) 2021 by the authors. Licensee MDPI, Basel, Switzerland. This article is an open access article distributed under the terms and conditions of the Creative Commons Attribution (CC BY) license (https:/ / creativecommons.org/licenses/by/ $4.0 /)$.

\begin{abstract}
Controlled environment agriculture (CEA) technologies are required to meet current and future food production demand as the global population rises, arable land decreases, and minerals for fertilizer production are depleted. Hydroponics and recirculating aquaculture systems (RAS) are intensive production methods that can provide season-independent vegetables and seafood in urban settings but are limited by a reliance on fertilizing solutions made from finite mineral reserves and the treatment and disposal costs of nutrient rich effluent, respectively. The development of a capture and reuse system where RAS effluent is solubilized to become plant-available and utilized as a hydroponic nutrient solution would aid both industries and increase food security in urban food deserts. Aerobic mineralization is used in domestic wastewater treatment to reduce solid content and solubilize particulate-bound nutrients. Preliminary studies have also shown that aerobic mineralization can be an effective method for RAS effluent treatment. Aerobic batch reactors were used to mineralize RAS effluent in this study. Suspended solids reduction achieved in the reactors was measured throughout the experiment and the plant-availability of twelve nutrients was determined before and after treatment. It was shown that aerobic mineralization can effectively reduce particulate-bound solids and solubilize nutrients to increase plant utilization in RAS effluent.
\end{abstract}

Keywords: controlled environment agriculture; circular nutrient economy; aquaculture waste mineralization; hydroponics

\section{Introduction}

Controlled environment agriculture (CEA) optimizes environmental growth parameters for year-round fruit, vegetable, and seafood production. This optimization allows greater growth rates and yields in a smaller area, with less water than traditional agricultural methods [1,2]. The increased utilization of CEA technologies will be required to meet the food demands of the growing global population and counter the reduction in farmable lands as a result of urbanization [3]. Recirculating aquaculture systems (RAS) and hydroponic crop production are two of the most prominent and economically stable CEA methods [1,2]. However, both industries are facing unique challenges preventing further expansion.

Extensive waste treatment and removal processes allow well-maintained RAS to reuse up to $99 \%$ of total system water daily and use between $90-99 \%$ less water than other aquaculture methods [2]. As a result of the waste removal processes, RAS generates a concentrated and nutrient rich effluent that requires additional treatment before discharge to prevent polluting natural waterways [4-7]. Effluent treatment and internal 
water treatment costs are the primary contributor to the prevention of RAS expansion, limiting the availability of location-independent fresh seafood production methods in urban food deserts [4-7].

Similar to RAS, hydroponics can result in location-independent production with superior yield to cropping area ratios, while using less water than its traditional agriculture counterparts [8]. However, unlike the RAS industry, which is limited by excessive nutrient production, the hydroponic industry is limited by the need for an additional input of nutrients as it is reliant on the finite mineral reserves used for synthetic nutrient solutions $[9,10]$. Developing a capture and reuse waste management system similar to terrestrial agriculture would have a multi-faceted effect on the CEA industry by turning RAS effluent into a value-added product, thereby providing the hydroponic industry with a naturally derived nutrient source.

Previous research identified that RAS effluent contains the essential macro- and micronutrients for plant growth but requires additional treatment to mineralize particulatebound nutrients to increase plant availability [11-15]. Several studies have shown that aerobic mineralization can be an effective method for reducing solids content and solubilizing nutrients in RAS effluent [14,16-18]. However, no published work has analyzed solubilization across an array of plant essential nutrients or tracked solids mineralization across multiple time points in aerobically treated direct RAS discharge that had not undergone a pre-processing phase in a single study period [14,16-18]. This research analyzed the aerobic treatment of unprocessed effluent directly from a pilot RAS, operated at industry standard stocking densities and feed rates to provide a waste stream commensurate with commercial production $[19,20]$. The total and plant available mass of twelve nutrients in unprocessed RAS effluent were identified, the degree of nutrient solubilization achieved by a lab-scaled aerobic bioreactor was determined, and the solids reduction achieved by aerobic treatment was determined. Aerobic treatment significantly reduced total suspended solids (TSS) concentration and increased the percent of the total nutrient mass dissolved into the treated solution. The correlation of TSS reduction and nutrient solubilization over time may be used to further determine hydraulic retention times (HRT) for largerscale treatment systems. Optimization opportunities were identified to refine the nutrient mineralization process.

\section{Materials and Methods}

\subsection{Fish Facility Description}

This study was conducted with effluent from the University of New Hampshire (UNH) Kingman Farm Recirculating Aquaponic Research Greenhouses (KFRAG) located in Madbury, New Hampshire, USA. At the time of effluent collection, the system had been operating at feed and waste production rates, established in the literature as commensurate with industrial RAS standards, for over one year without any prominent changes to the system that would influence data analysis $[19,20]$. The $15 \mathrm{~m}^{3}$ recirculating system was comprised of a $3 \mathrm{~m}^{3}$ fish tank for Nile Tilapia (Oreochromis niloticus) culture, a rotary drum screen filter (PR Aqua model RFM2014) fitted with 54 micron screens, a $1.3 \mathrm{~m}^{3}$ mixed media bed bioreactor (MMBR) for nitrification, a $200 \mathrm{~L}$ pumping reservoir, a $300 \mathrm{~L}$ stand pipe well, and three $12.6 \mathrm{~m}^{2}$ deep water raft (DWR) beds $\left(3.4 \mathrm{~m}^{3}\right.$ each) for hydroponic butterhead lettuce (Lactuca sativa var. capitata) production to make up the remaining system volume. All nutrients used to grow crops were supplied through the fish feed ( $3 \mathrm{~mm}$ floating, Finfish Silver, 40\% protein, 10\% lipid, Zeigler Bros. Inc., Gardner, PA, USA) except for periodic diethylemetriamine pentaacetic acid (DTPA) iron (III) salt additions to maintain required iron ( $\mathrm{Fe}$ ) concentrations for optimum lettuce growth and daily additions of potassium carbonate $\left(\mathrm{K}_{2} \mathrm{CO}_{3}\right)$ to maintain system alkalinity at $40 \mathrm{mg} / \mathrm{L} \mathrm{CaCO}$ for biofilter management [21,22]. Fish were fed $1300 \mathrm{~g} /$ day. A constant biomass approach was used to maintain a fish stocking density of $36 \mathrm{~kg} / \mathrm{m}^{3}$. Bi-weekly fish biomass was measured and adjusted to ensure that $1300 \mathrm{~g} /$ day of feed would provide optimal fish growth rates per Delong et al. [20]. 


\subsection{Drum Screen Effluent Collection and Analysis}

A total of $200 \mathrm{~L}$ of effluent was collected from the rotary drum filter over $72 \mathrm{~h}$ to provide a composite sample for analysis that captured multiple feeding and excrement cycles for the fish. The effluent was constantly aerated during collection to prevent anaerobic conditions and preserve the nitrogen $(\mathrm{N})$ mass. The effluent was well mixed to provide a representative composite sample and immediately analyzed.

The effluent was separated into aqueous and particulate fractions prior to analysis with 1.5-micron glass fiber filters. For this study, nutrients in the aqueous fraction of the effluent were considered plant available as past studies have demonstrated that mineralized aquaponic/RAS effluent can be an effective fertilizing solution $[17,23]$. Measurement of TSS concentration and $\mathrm{pH}$ was conducted at the UNH Agricultural Engineering Laboratory using the APHA Method 2540D [24] and a Fisher Scientific Accument AB250 (Waltham, MA, USA), respectively.

The nutrient analysis of the separated aqueous and particulate effluent fractions was conducted by JR Peters Laboratory, a commercial hydroponic solution development and testing laboratory in Allentown, PA, USA. Specific nutrients analyzed included N, phosphorus $(\mathrm{P})$, potassium $(\mathrm{K})$, calcium $(\mathrm{Ca})$, magnesium $(\mathrm{Mg}), \mathrm{Fe}$, manganese $(\mathrm{Mn})$, copper $(\mathrm{Cu})$, zinc $(\mathrm{Zn})$, sodium $(\mathrm{Na})$, aluminum $(\mathrm{Al})$, and boron (B). Particulate analysis was conducted using combustion and an organic element analyzer on the glass fiber filters was used to separate the particles and liquid. Filter blanks were analyzed to prevent extraneous nutrients from effecting results. All filters were dried for at least $72 \mathrm{~h}$ at $110^{\circ} \mathrm{C}$ before being ground and sent out for analysis. Inductively coupled mass atomic emission spectrometry was used to analyze the concentration of nutrients in the filtrate.

A total concentration, in $\mathrm{mg} / \mathrm{L}$, for each nutrient was calculated to characterize the total mass of each nutrient regardless of form. This concentration was based on total nutrient mass and reactor volume. The analysis for the aqueous fraction of the effluent was reported in mg/L. Particulate nutrient masses for macro-nutrients (N, P, K, Ca, and Mg) were reported as a percentage of the TSS mass. The following equation was developed in Tetreault et al., [13] to normalize nutrients reported as a percent of the TSS mass as mg/L:

$$
\mathrm{M}_{\text {solids, } \%}=[\mathrm{TSS}] \times \mathrm{C}_{\%}
$$

where the normalized nutrient mass (as $\mathrm{mg} / \mathrm{L}$ ) for the entire reactor is represented by

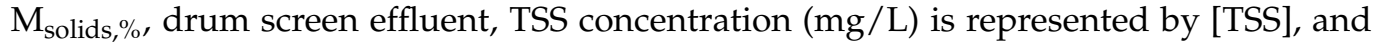
the percent of the total reactor TSS that an individual nutrient's massed comprises is represented by $\mathrm{C}_{\%}$. Particulate nutrient masses for micro-nutrients ( $\mathrm{Fe}, \mathrm{Mn}, \mathrm{Cu}, \mathrm{Zn}, \mathrm{Na}, \mathrm{Al}$, and B) were reported as $\mathrm{mg}$ nutrient $/ \mathrm{kg}$ TSS. The following equation was developed in Tetreault et al., [13] to normalize nutrients reported as mg nutrient $/ \mathrm{kg}$ TSS:

$$
\mathrm{M}_{\text {solids, } \mathrm{f}}=\frac{[\mathrm{TSS}] \times \mathrm{C}_{\mathrm{f}}}{\mathrm{V}_{\text {effluent }}}
$$

where the total nutrient mass divided by the total volume of the reactor $(\mathrm{mg} / \mathrm{L})$ is represented by $\mathrm{M}_{\text {solids, } \mathrm{f}}$, the TSS concentration of reactor waste water $(\mathrm{kg} / \mathrm{L})$ is represented by [TSS], the specific mass fraction of an individual nutrient in TSS ( $\mathrm{mg}$ nutrient $/ \mathrm{kg}$ TSS) is represented by $C_{f}$, and the total volume of effluent treated in the reactor is represented by $\mathrm{V}_{\text {effluent. }}$. The particulate and aqueous concentrations were totalized to determine the total nutrient concentration. The percent of the total nutrient concentration that was considered plant available was the percent of the total concentration in the aqueous fraction.

\subsection{Reactor Design, Operation, and Sample Analysis}

Effluent treatment was conducted using $20 \mathrm{~L}$ of high-density polyethylene (HDPE) aerobic reactors (Figure 1). The effluent was continuously mixed using constant aeration from an air pump (Sweetwater Linear II Model SNL42, Pentair, Minneapolis, MN, USA) with a medium pore stone diffuser. 


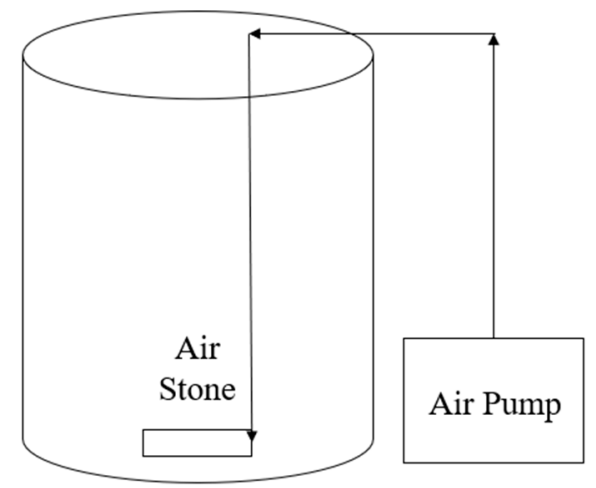

Figure 1. Aerobic reactor schematic. Effluent to be treated was continuously mixed using constant aeration. Samples were taken by removing the reactor lid to access the effluent.

The aerobic reactors were operated in triplicate at ambient temperature. The experiment was conducted for 15 days to correspond with previously established retention times for RAS effluent treatment reported in Delaide et al., [16]. Reactors were filled with $15 \mathrm{~L}$ of drum screen effluent. Reactors were not inoculated and used only the endogenous microbes present during collection. A $50 \mathrm{~mL}$ sample was taken from each reactor every $48 \mathrm{~h}$ and immediately analyzed for temperature, $\mathrm{pH}$, TSS, and dissolved oxygen (DO). A Hach (Loveland, CO, USA) HQ 40D was used for DO measurements and a Fisher Scientific Accumet AB250 (Waltham, MA, USA) was used for $\mathrm{pH}$ measurements. To account for evaporation, effluent height in each reactor was marked daily. Volume lost due to evaporation was replaced with reverse osmosis (RO) water to avoid artificially increasing nutrient concentrations. Effluent removed for sample analysis was not replaced with RO water to avoid artificially diluting nutrient concentrations. A final nutrient analysis for the particulate and aqueous fractions of each reactor was conducted after 15 days following the same procedures as the initial effluent analysis to determine if a change in plant availability occurred. The following equation was developed in Tetreault et al., [13] to determine the change in plant availability of a specific nutrient after a mineralization treatment:

$$
\Delta \mathrm{M}_{\text {aqueous }}=\frac{\left[\mathrm{B}_{\text {aqueous }}\right] /\left[\mathrm{B}_{\text {total }}\right]}{\left[\mathrm{A}_{\text {aqueous }}\right] /\left[\mathrm{A}_{\text {total }}\right]}
$$

where the percent change of the total nutrient concentration $(\mathrm{mg} / \mathrm{L})$ in aqueous fraction of effluent is represented by $\Delta \mathrm{M}_{\mathrm{aqueous}}$, and the aqueous and total nutrient concentrations $(\mathrm{mg} / \mathrm{L})$ of initial effluent $(\mathrm{A})$ and treated effluent $(\mathrm{B})$ are represented by $\left[\mathrm{A}_{\mathrm{aqueous}}\right],\left[\mathrm{A}_{\text {total }}\right]$, $\left[\mathrm{B}_{\text {aqueous }}\right]$, and $\left[\mathrm{B}_{\text {total }}\right]$, respectively.

\subsection{Statistical Analysis}

A Tukey's honestly significant difference (HSD) test was used to determine if DO, $\mathrm{pH}$, and temperature in the replicate reactors were significantly similar or different from each other throughout the study period. The significance of the difference between the TSS concentration of the untreated effluent and of the final treated solution was calculated with a pooled $t$-test. A $p$ value $<0.05$ was considered significant in all tests.

\section{Results}

\subsection{Effluent Nutrient Analysis}

The untreated composite effluent sample had a TSS concentration and $\mathrm{pH}$ of $1217 \mathrm{mg} / \mathrm{L}$ and 7.4, respectively. The total concentration, and percent of the total in the aqueous and particulate fraction, of the twelve analyzed nutrients in the untreated effluent are reported in Table 1. 
Table 1. Total nutrient concentrations in the drum screen effluent collected from UNH KFRAG as a combination of the aqueous and particulate nutrient mass normalized to $1 \mathrm{~L}$ of effluent. The aqueous and particulate mass fractions for each nutrient are expressed as a percent of total mass. Nutrients found in the aqueous fraction were considered plant available.

\begin{tabular}{cccc}
\hline Nutrient & $\begin{array}{c}\text { Total Drum Screen } \\
\text { Effluent (mg/L) }\end{array}$ & $\begin{array}{c}\text { Aqueous } \\
\mathbf{( \% )}\end{array}$ & $\begin{array}{c}\text { Particulate } \\
\text { (\%) }\end{array}$ \\
\hline Macro-nutrient & & & \\
$\mathrm{N}$ & 174 & 96.36 & 3.64 \\
$\mathrm{P}$ & 3.82 & 68.11 & 31.89 \\
$\mathrm{~K}^{+}$ & 402 & 99.61 & 0.39 \\
$\mathrm{Ca}$ & 30.4 & 92.78 & 7.22 \\
$\mathrm{Mg}$ & 21.8 & 98.33 & 1.67 \\
Micro-nutrient & & & 5.43 \\
$\mathrm{Fe}^{+}$ & 1.90 & 94.57 & 2.50 \\
$\mathrm{Mn}$ & 0.27 & 97.50 & 9.89 \\
$\mathrm{~B}$ & 0.26 & 90.11 & 5.40 \\
$\mathrm{Cu}$ & 0.17 & 94.60 & 0.76 \\
$\mathrm{Zn}$ & 0.80 & 99.24 & 0.28 \\
$\mathrm{Na}$ & 34.5 & 99.72 & 28.85 \\
$\mathrm{Al}$ & 0.51 & 71.15 & \\
\hline
\end{tabular}

${ }^{\dagger}$ Supplemented Nutrient in KFRAG.

\subsection{Reactor Sample Analysis}

The mean \pm standard deviation (SD) of the aerobic reactor temperature, $\mathrm{DO}$, and $\mathrm{pH}$ are reported in Table 2 . The mean \pm SD in the TSS measurements taken every $48 \mathrm{~h}$ is reported in Figure 2. On day 15, the final mean TSS \pm SD concentration was reduced from the untreated effluent by $60.96 \% \pm 0.43 \%(p<0.0001)$. Samples collected from each of the replicate reactors throughout the $48 \mathrm{~h}$ interval measurements showed no significant differences $(p=0.9647)$.

Table 2. The mean $\pm \mathrm{SD}$ of the temperature, $\mathrm{DO}$, and $\mathrm{pH}$ in the reactors throughout the study period.

\begin{tabular}{ccc}
\hline Parameter & Aerobic Reactors & $\boldsymbol{p}$-Value between Reactors \\
\hline Temperature $\left({ }^{\circ} \mathrm{C}\right)$ & $21.1 \pm 0.41$ & 0.0018 \\
$\mathrm{DO}(\mathrm{mg} / \mathrm{L})$ & $8.83 \pm 0.20$ & 0.3818 \\
$\mathrm{pH}$ & $7.3 \pm 0.18$ & 0.3639 \\
\hline
\end{tabular}

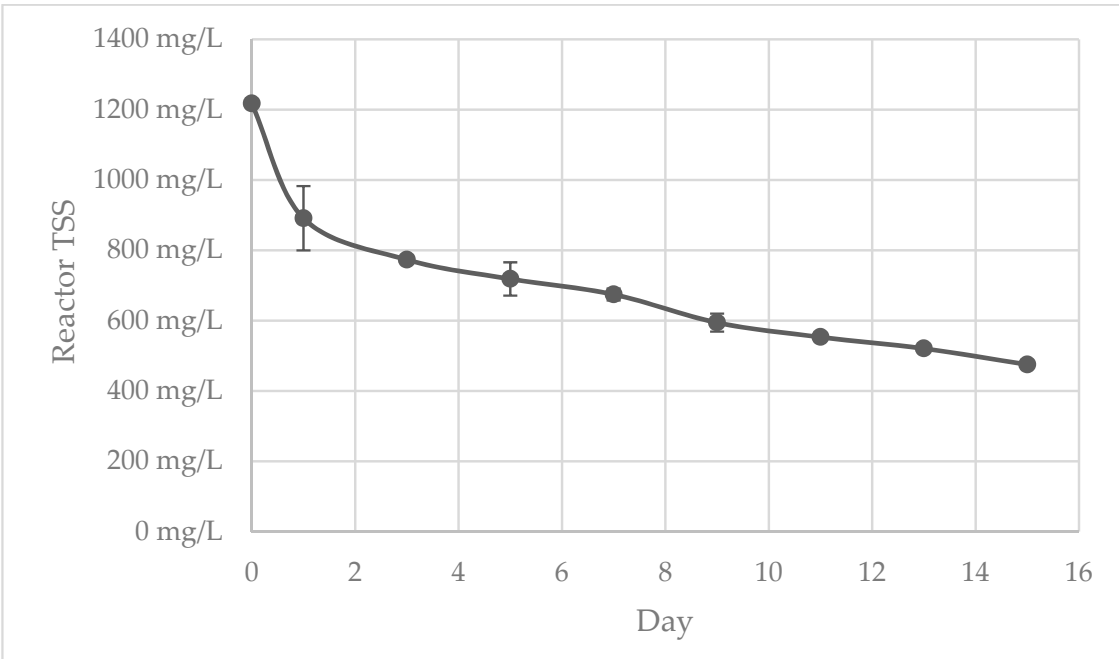

Figure 2. Mean TSS concentration within aerobic reactors throughout the 15-day study period. Error bars indicate standard deviation between treatment replicates. 


\subsection{Final Nutrient Analysis}

The change in the amount of the total nutrient concentration in the aqueous fraction of the treated effluent are reported in Table 3. After aerobic treatment, the percent of the total $\mathrm{N}, \mathrm{P}, \mathrm{Ca}, \mathrm{B}, \mathrm{Cu}$, and $\mathrm{Al}$ in the aqueous fraction of the effluent was significantly increased. The aqueous $\mathrm{N}$ after treatment was comprised of $98.07 \%$ nitrate-nitrogen $\left(\mathrm{NO}_{3}-\mathrm{N}\right), 1.06 \%$ urea, and $0.87 \%$ ammonia-nitrogen (TAN).

Table 3. Increase of total nutrient concentrations in aqueous form (and available for plant uptake) in tilapia effluent after treatment. Mean percent \pm SD of total nutrients in aqueous form shown before and after treatment. Statistical significance of untreated effluent and aerobic solution described by $p$-value.

\begin{tabular}{cccc}
\hline Nutrient & $\begin{array}{c}\text { Effluent } \\
\text { (\% Aqueous) }\end{array}$ & $\begin{array}{c}\text { Aerobic } \\
\text { (\% Aqueous) }\end{array}$ & $p$-Value \\
\hline Macro-nutrients & & & $<0.0001$ \\
$\mathrm{~N}$ & 96.36 & $98.60 \pm 0.1$ & $<0.0001$ \\
$\mathrm{P}$ & 68.11 & $94.97 \pm 1.1$ & $<0.001$ \\
$\mathrm{~K}^{\dagger}$ & 99.61 & $99.84 \pm 0.0$ & $<0.001$ \\
$\mathrm{Ca}$ & 92.78 & $96.59 \pm 0.6$ & $<0.01$ \\
$\mathrm{Mg}$ & 98.33 & $99.4 \pm 0.2$ & $=0.1529$ \\
Micro-nutrient & & & $=0.6611$ \\
$\mathrm{Fe}$ & 94.57 & $93.64 \pm 0.9$ & $<0.0001$ \\
$\mathrm{Mn}$ & 97.50 & $96.67 \pm 2.8$ & $<0.001$ \\
$\mathrm{~B}$ & 90.11 & $99.84 \pm 0.1$ & $<0.01$ \\
$\mathrm{Cu}$ & 94.60 & $98.57 \pm 0.6$ & $<0.001$ \\
$\mathrm{Zn}$ & 99.24 & $99.84 \pm 0.1$ & $<001$ \\
$\mathrm{Na}$ & 99.72 & $99.98 \pm 0.0$ & $86.74 \pm 0.9$ \\
$\mathrm{Al}$ & 71.15 & &
\end{tabular}

${ }^{\dagger}$ Nutrient supplemented at KFRAG.

\section{Discussion}

\subsection{Untreated Effluent Nutrient Profile}

The nutrient profile of the KFRAG effluent was similar to reports of effluent from other aquaponic/RAS effluent used in mineralization research [12-14,16]. Specifically, P, Ca, Mg, and $\mathrm{Fe}$ have been consistently found to be particulate-bound in effluent across a variety of systems with differing fish species and system designs [12-14,16]. In this study, B and Al were also identified as particulate-bound nutrients in the untreated effluent. Additionally, the routine addition of soluble $\mathrm{K}_{2} \mathrm{CO}_{3}$, for biofilter maintenance, and Fe salts increased the plant availability of these nutrients in the KFRAG effluent when compared to findings in other studies [12-16,22]. Additionally, some studies have utilized a pre-treatment process to consolidate the particulate portion of the effluent before mineralization $[18,25]$. These studies allowed the effluent to settle before decanting and resuspending in RAS water at approximately $10 \mathrm{~g} / \mathrm{kg}$, while others used effluent directly from the RAS solids removal unit $[13,14,18,25]$. The variations suggest that while certain patterns can be identified across aquaponic/RAS effluent, specific management practices can influence effluent composition and any individual system should not serve as a template for the industry.

Conducting treatment research on direct and consolidated effluent is beneficial in identifying the most effective and on-farm appropriate treatment processes and should be considered when directly comparing reported nutrient masses and concentrations from different studies. One benefit of using effluent directly from an RAS/aquaponic system without pre-treatment consolidation is the capture of the nutrients already dissolved in the aqueous fraction of the effluent. This study demonstrated that the aqueous fraction of the effluent already contains most of the nutrient mass removed by a drum screen. Consolidating the particulate fraction of the effluent may be an efficient method to reduce the total volume requiring treatment, but decanting the aqueous effluent fraction removes a valuable nutrient source. While the nutrients in the aqueous fraction may be plant 
available, multiple studies have established that it also contains organic carbon (OC) that can limit plant growth and foster pathogens [26,27]. Due to the OC mass, treatment of the separated aqueous would still be beneficial when developing a hydroponic nutrient solution. Continued research on the benefits of consolidating or using direct effluent is required, and each method may be ideal for different operations and treatment goals.

\subsection{Solids Reduction}

The mean \pm SD TSS concentration reduction of $60.96 \pm 0.43 \%$ achieved by the aerobic treatment was similar to the reduction of $60.8 \%$ reported by Delaide et al. [16] in an aquaponic mineralization study with a comparative aerobic reactor design and 15-day HRT. While the percent reduction is similar in both experiments, the routine TSS sampling in this study provided additional insight into the rate of solids mineralization. By day 5 and day 9 , $67.19 \pm 1.64 \%$ and $83.91 \pm 1.41 \%$ of the TSS reduction achieved throughout the 15-day experiment was completed, respectively. During the final 6 days of reactor operations only $16.09 \pm 1.41 \%$ of the overall reduction in TSS concentration occurred. As the majority of the TSS concentration was removed from the effluent early in the treatment process, consideration should be taken regarding the benefit of extended treatment compared to the cost of treatment. These results are important in transitioning from laboratory scale experiments to designing a flow-through system capable of treating RAS effluent at production scale.

Data across studies regarding the anaerobic treatment of aquaponic/RAS effluent have been less consistent, making comparisons between the TSS reduction achieved in the different microbial treatment methods difficult $[13-16,18,25]$. Tetreault et al., [13] reported a 15-day TSS reduction of $76.17 \pm 6.97 \%$ with anaerobic treatment, while Delaide et al., [16] reported a TSS reduction of $49.02 \%$ in a semi-batch anaerobic treatment with a 15-day HRT. Further research on solids reductions in RAS effluent achieved by anaerobic treatment is required to accurately compare these two common microbial wastewater treatment methods.

\subsection{Treated Effluent Nutrient Profile}

Out of the seven nutrients that were most particulate bound in the untreated effluent from KFRAG, six (N, P, Ca, B, Cu, and $\mathrm{Al}$ ) were made significantly more plant available as a result of aerobic treatment. Only Fe did not have a significant increase in the aqueous fraction of its total concentration. The presence, and mineralization potential, of P in RAS effluent may become an important supplement to the CEA industry in coming decades. Recent research suggests mineral $P$ depletions in the near future resulting from agricultural needs [28]. The reuse of a consistent, and currently underutilized, P source will reduce dependence on the finite mineral reserves. As noted above, variations in aquaponic/RAS system management and effluent consolidation before treatment can make direct comparisons between nutrient masses across studies difficult. However, other works have shown similar results to this study regarding the effectiveness of aerobic treatment to increase nutrient solubilization $[14,16,25]$.

\subsection{Implications for Aquaponic Production}

Aquaponics is the combination of hydroponics and RAS where crops are grown using feed that has been consumed, broken down, and excreted by fish as dissolved plant-available nutrients [29]. The solid fish effluent, such as that treated in this study, is often removed as it is not plant available and contains OC [2]. Aquaponic systems can be either coupled, with fish and plants sharing waste treatment and culture water in one system, or decoupled, with a controlled water flow from a RAS to a hydroponic system that does not return water to the fish system [30]. With fish feed being the primary nutrient source, coupled aquaponic systems can have reduced nutrient masses when compared to hydroponic systems [31]. The combined nature of coupled aquaponics prevents the addition of chemical hydroponic nutrient solutions to avoid negative effects on fish health. 
While decoupled aquaponic systems are able to supplement with traditional hydroponic solutions, this does not fully shift away from the reliance on finite mineral reserves. The treatment and reutilization of fish solid waste would allow the natural supplementation of nutrients in both aquaponic system designs.

\subsection{Future Research}

The consistent measurements of TSS concentration in this study can be used to better understand solids mass reduction over time than previously reported and allow a more efficient treatment process to minimize treatment times and maximize nutrient availability. Research to identify mineralization rates of the most particulate-bound nutrients and a comparison of TSS to volatile suspended solids (VSS) concentration will allow a more accurate determination of complete treatment time.

Excessive OC in hydroponic nutrient solutions can result in biofilm build-up that can block irrigation tubing and serve as a fuel source for the proliferation of pathogenic bacteria, making the removal of OC important before any waste can be utilized as a hydroponic nutrient solution [26,27]. While aerobic mineralization has been shown to remove OC from municipal and agriculture wastewater, only limited data is currently available in regards to OC removal in aquaponic/RAS effluent [16]. Future research would benefit from consistent OC measurements in correspondence with TSS and aqueous nutrient concentration measurements to provide a more accurate HRT for a treatment system. Two-stage anaerobic to aerobic treatment is commonly used for municipal and terrestrial agriculture waste [32,33]. This combined approach has been shown to be more effective at reducing TOC and total solids than the individual use of either method [32,33]. The development of ideal HRTs for both processes in batch conditions could be used as a template for developing a two-stage flow-through model.

\section{Conclusions}

This study confirmed that aerobic treatment can significantly reduce TSS concentration and increase nutrient solubilization in aquaponic/RAS effluent. Expansion upon previous research was achieved through consistent measurements of TSS concentration over time and in direct drum screen discharge that had not been concentrated pre-treatment. The use of direct effluent retained a large portion of the total nutrient mass already dissolved in the aqueous effluent fraction and could be scaled to allow a simplistic treatment unit to be incorporated into coupled aquaponic system designs. The consistent TSS measurements provided a more accurate description of TSS evolution temporally, which may be used to optimize further treatment processes and refine the flow-through treatment systems typically utilized in small-scale aquaponics systems currently. Future research would benefit from regular measurements of TOC and aqueous nutrient concentrations to provide data that can be used to develop a flow-through or combined anerobic treatment system.

Author Contributions: Conceptualization, J.T. and T.G.; methodology, J.T. and T.G.; validation, J.T.; formal analysis, J.T. and T.G.; investigation, J.T.; resources, J.T. and T.G.; data curation, J.T.; writing—original draft preparation, J.T.; writing—review and editing, J.T., T.G. and R.F.; visualization, J.T., R.F. and T.G.; supervision, J.T.; project administration, J.T.; funding acquisition, T.G. and R.F. All authors have read and agreed to the published version of the manuscript.

Funding: This work was funded in part by a grant from New Hampshire Sea Grant, Project R/SFA-8, pursuant to National Oceanic and Atmospheric Administration Award No. NA18OAR4170090. Partial funding was provided by the New Hampshire Agricultural Experiment Station (Scientific Contribution Number NH00648). This work was supported by the USDA National Institute of Food and Agriculture Hatch Project (1010110).

Institutional Review Board Statement: Not Applicable.

Informed Consent Statement: Not Applicable. 
Data Availability Statement: Data is reported in the Results section. Please contact the corresponding author for any additional information.

Conflicts of Interest: The authors declare no conflict of interest.

\section{References}

1. Sharma, N.; Acharya, S.; Kumar, K.; Singh, N.; Chaurasia, O. Hydroponics as an advanced technique for vegetable production: An overview. J. Soil Water Conserv. 2019, 17, 364-376. [CrossRef]

2. Timmons, M.; Guerdat, T.; Vinci, B.J. Recirculating Aquaculture, 4th ed.; Ithaca Publishing Company, LLC: Vero Beach, FL, USA, 2018; pp. 2-25, 663-707.

3. Hunter, M.; Smith, R.; Schipanski, M.; Atwood, L.; Mortensen, D. Agriculture in 2050: Recalibrating Targets for Sustainable Intensification. Bioscience 2017, 67, 386-391. [CrossRef]

4. Miller, D.; Semmens, K. Waste Management in Aquaculture. Aquaculture 2002, 1-10. Available online: https://freshwateraquaculture.extension.org/wp-content/uploads/2019/08/WasteManagemetninAquaculture.pdf (accessed on 14 July 2021).

5. EPA (United States Environmental Protection Agency). Effluent Limitations Guidelines and New Source Performance Standards for the Concentrated Aquatic Animal Production Point Source Category; Final Rule. 40 CFR Part 451; EPA: Washington, DC, USA, 2004.

6. Sharrer, M.; Rishel, K.; Taylor, A.; Vinci, B.J.; Summerfelt, S.T. The cost and effectiveness of solids thickening technologies for treating backwash and recovering nutrients from intensive aquaculture systems. Bioresour. Technol. 2010, 101, 6630-6641. [CrossRef] [PubMed]

7. Tsani, S.; Koundouri, P. A Methodological Note for the Development of Integrated Aquaculture Production Models. Front. Mar. Sci. 2018, 4, 406. [CrossRef]

8. Lages Barbosa, G.; Almeida Gadelha, F.; Kublik, N.; Proctor, A.; Reichelm, L.; Weissinger, E.; Wohlleb, G.; Halden, R. Comparison of Land, Water, and Energy Requirements of Lettuce Grown Using Hydroponic vs. Conventional Agricultural Methods. Int. J. Environ. Res. Public Health 2015, 12, 6879-6891. [CrossRef]

9. Henckens, M.L.C.M.; van Ierland, E.; Driessen, P.P.J.; Worrell, E. Mineral resources: Geological scarcity, market price trends, and future generations. Resour. Policy 2016, 49, 102-111. [CrossRef]

10. Yogev, U.; Sowers, K.R.; Mozes, N.; Gross, A. Nitrogen and carbon balance in a novel near-zero water exchange saline recirculating aquaculture system. Aquaculture 2017, 467, 118-126. [CrossRef]

11. Chen, S.; Coffin, D.; Malone, R. Sludge Production and Management for Recirculating Aquacultural Systems. J. World Aquac. Soc. 1997, 28, 303-315. [CrossRef]

12. Guerdat, T.C.; Losordo, T.M.; Delong, D.P.; Jones, R.D. An evaluation of solid waste capture from recirculating aquaculture systems using a geotextile bag system with a flocculant-aid. Aquac. Eng. 2013, 54, 1-8. [CrossRef]

13. Tetreault, J.; Fogle, R.; Guerdat, T. Anaerobic Mineralization of Recirculating Aquaculture Drum Screen Effluent for Use as a Naturally-Derived Nutrient Solution in Hydroponic Cropping Systems. Conservation 2021, 1, 151-167. [CrossRef]

14. Monsees, H.; Keitel, J.; Paul, M.; Kloas, W.; Wuertz, S. Potential of aquacultural sludge treatment for aquaponics: Evaluation of nutrient mobilization under aerobic and anaerobic conditions. Aquac. Environ. Interact. 2017, 9, 9-18. [CrossRef]

15. Goddek, S.; Delaide, B.P.; Joyce, A.; Wuertz, S.; Jijakli, M.H.; Gross, A.; Eding, E.H.; Bläser, I.; Reuter, M.; Keizer, L.P.; et al. Nutrient mineralization and organic matter reduction performance of RAS-based sludge in sequential UASB-EGSB reactors. Aquac. Eng. 2018, 83, 10-19. [CrossRef]

16. Delaide, B.; Goddek, S.; Keesman, K.J.; Jijakli, M.H.M. A methodology to quantify the aerobic and anaerobic sludge digestion performance for nutrient recycling in Aquaponics. Biotechnol. Agron. Soc. Environ. 2018, 22, 106-112.

17. Delaide, B.; Panana, E.; Teerlinck, S.; Bleyaert, P. Suitability of supernatant of aerobic and anaerobic pikeperch (Sander lucioperca L.) sludge as a water source for hydroponic production of lettuce (Lactuca sativa L. var. capitata). Aquacult Int. 2021, 29, 1721-1735. [CrossRef]

18. Khiari, Z.; Kaluthota, S.; Savidov, N. Aerobic bioconversion of aquaculture solid waste into liquid fertilizers: Effects of bioprocess parameters on kinetics of nitrogen mineralization. Aquaculture 2019, 500, 492-499. [CrossRef]

19. Losordo, T.M.; Hobbs, A.O.; DeLong, D.P. The design and operational characteristics of the CP\&L/EPRI fish barn: A demonstration of recirculating aquaculture technology. Aquac. Eng. 2000, 22, 3-16.

20. DeLong, D.; Losordo, T.; Rakocy, J. Tank Culture of Tilapia; Southern Regional Aquaculture Center: Stoneville, MS, USA, 2009.

21. Mattson, N.; Peters, C. A Recipe for Hydroponic Success. Inside Grower, January 2014; pp. 16-19. Available online: https: / / dokumen.tips/documents/a-recipe-for-hydroponic-successpdf.html (accessed on 14 July 2021).

22. Anderson, T. Biological Responses of Lettuce to Hydroponic and Aquaponic Conditions. Master's Thesis, Cornell University, Ithaca, NY, USA, 2016.

23. Goddek, S.; Schmautz, Z.; Scott, B.; Delaide, B.; Keesman, K.J.; Wuertz, S.; Junge, R. The Effect of Anaerobic and Aerobic Fish Sludge Supernatant on Hydroponic Lettuce. Agronomy 2016, 6, 37. [CrossRef]

24. Standard Methods. Standard Methods for the Examination of Water and Wastewater, 19th ed.; American Public Health Association: Washington, DC, USA, 2012; pp. 2-71.

25. Panana, E.; Delaide, B.; Teerlinck, T.; Bleyaert, P. Aerobic treatment and acidification of pikeperch (Sander lucioperca L.) sludge for nutrient recovery. Aquacult. Int. 2021, 29, 1-14. [CrossRef] 
26. Lee, J.G.; Lee, B.Y.; Lee, H.J. Accumulation of phytotoxic organic acids in reused nutrient solution during hydroponic cultivation of lettuce (Lactuca sativa L.). Sci. Hortic. 2006, 110, 119-128. [CrossRef]

27. Yaron, S.; Römling, U. Biofilm formation by enteric pathogens and its role in plant colonization and persistence. Microb. Biotechnol. 2014, 7, 496-516. [CrossRef]

28. Cordell, D.; Drangert, J.-O.; White, S. The story of phosphorus: Global food security and food for thought. Glob. Environ. Chang. 2009, 19, 292-305. [CrossRef]

29. Rakocy, J.; Masser, P.; Losordo, T. Recirculating Aquaculture Tank Production Systems: Aquaponics—Integrating Fish and Plant Culture; SRAC-454; Southern Regional Aquaculture Center: Stoneville, MS, USA, 2006.

30. Goddek, S.; Joyce, A.; Kotzen, B.; Burnell, G. Aquaponics Food Production Systems: Combined Aquaculture and Hydroponic Production Technologies for the Future; Springer Open: Berlin/Heidelberg, Germany, 2019; pp. 163-229.

31. Kloas, W.; Gross, R.; Baganz, D.; Graupner, J.; Monsees, H.; Schmidt, U.; Staaks, G.; Suhl, J.; Tschirner, M.; Wittstock, B.; et al. A new concept for aquaponics systems to improve sustainability, increase productivity, and reduce environmental impacts. Aquac. Environ. Interact. 2015, 7, 179-192. [CrossRef]

32. Borzacconi, L.; López, I.; Ohanian, M.; Viñas, M. Anaerobic-Aerobic Treatment of Municipal Solid Waste Leachate. Environ. Technol. 1999, 20, 211-217. [CrossRef]

33. Del Pozo, R.; Diez, V. Organic matter removal in combined anaerobic-aerobic fixed-film bioreactors. Water Res. 2003, 37, 3561-3568. [CrossRef] 